\title{
Characterization and genetic diversity of pepper (Capsicum spp) parents and interspecific hybrids
}

\author{
M.P.S.D. Costa ${ }^{1}$, M.M. do Rêgo ${ }^{1}$, A.P.G. da Silva ${ }^{2}$, E.R. do Rêgo ${ }^{1}$ and \\ P.A. Barroso ${ }^{1}$ \\ ${ }^{1}$ Universidade Federal da Paraíba, Centro de Ciências Agrárias, Campus II, \\ Areia, PB, Brasil \\ ${ }^{2}$ Universidade Estadual do Sudoeste da Bahia, Campus Juvino Oliveira, \\ Itapetinga, BA, Brasil \\ Corresponding authors: M.P.S.D. Costa / M.M. Rêgo \\ E-mail: agro30costa@gmail.com / mailson@cca.ufpb.br \\ Genet. Mol. Res. 15 (2): gmr.15027652 \\ Received September 16, 2015 \\ Accepted December 7, 2015 \\ Published May 6, 2016 \\ DOI http://dx.doi.org/10.4238/gmr.15027652
}

\begin{abstract}
Pepper species exhibit broad genetic diversity, which enables their use in breeding programs. The objective of this study was to characterize the diversity between the parents of different species and their interspecific hybrids using morphological and molecular markers. The parents of Capsicum annuum (UFPB-01 and -137), C. baccatum (UFPB-72), and $C$. chinense (UFPB-128) and their interspecific hybrids $(01 \times 128,72 \times 128$, and $137 \times 128)$ were used for morphological and molecular characterization. Fruit length and seed yield per fruit (SYF) traits showed the highest variability, and three groups were formed based on these data. $\mathrm{CVg} / \mathrm{CVe}$ ratio values $(>1.0)$ were calculated for leaf length (1.67) and SYF (5.34). The trait that most contributed to divergence was the largest fruit diameter $(26.42 \%)$, and the trait that least contributed was pericarp thickness $(0.33 \%)$, which was subject to being discarded. The 17 primers produced 58 polymorphic bands that enabled the estimation of genetic diversity between parents and hybrids,
\end{abstract}


and these results confirmed the results of the morphological data analyses. The principal component analysis results also corroborated the morphological and random-amplified polymorphic DNA data, and three groups that contained the same individuals were identified. These results confirmed reports in the literature regarding the phylogenetic relationships of the species used as parents, which demonstrated that $C$. annuum was closer to C. chinense as compared to C. baccatum.

Key words: Capsicum spp; Genetic breeding; Genetic diversity; RAPD

\section{INTRODUCTION}

The study of genetic diversity in the genus Capsicum is necessary, because it provides parameters for the identification of parents that produce greater heterotic effects on progeny and increase the probability of obtaining superior genotypes in segregating generations (Sudré et al., 2005; Rêgo et al., 2009). Hybridization is a breeding method that is widely used in peppers (Capsicum spp), and it is able to generate new varietal sources (Rêgo et al., 2011a).

The genetic diversity of Capsicum species can be evaluated using several characteristics, including agronomic, morphological, and molecular traits (Rêgo et al., 2011a; Barroso et al., 2012; Nascimento et al., 2012). Using morpho-agronomic characterization, markers with high heritability, easy identification, and little genotype $\mathrm{x}$ environment interactions should be considered, and these characteristics allow the identification, preservation, and transfer of new sources of genetic variation (Bento et al., 2007; Rêgo et al., 2009; Nascimento et al., 2012). Molecular characterization has been a useful tool for the evaluation of genetic diversity in different plant species.

Moreover, molecular characterization is an efficient form used to study the partition of genetic variability between cultivated species and their wild relatives. This is because it clarifies phylogenetic relationships, providing rational strategies for breeding, germplasm collection, preservation, and the use of genetic resources (Rêgo et al., 2011b). Among the numerous molecular marker techniques, random-amplified polymorphic DNA (RAPD) is advantageous because of its simple use, low cost, and rapid generation of results, despite the low repeatability of results (Vieira et al., 2010; Rodrigues and Costa, 2011).

Total proteins represent another low-cost marker with easy access and rapid results, and they are also used to evaluate genetic variability. In addition, they have the potential to help to classify species, and they serve as markers for interspecific hybridization studies (Murphy et al., 1990; Lanham et al., 1994).

Therefore, the objective of this study was to characterize genetic diversity using morphological traits and molecular markers associated with the parents and interspecific hybrids of peppers (Capsicum spp). Moreover, the study aimed to utilize these data as a tool in programs focused on the breeding of parents and generations of more promising hybrids.

\section{MATERIAL AND METHODS}

Accessions belonging to the Active Germplasm Bank of Capsicum from UFPB, located in Areia, PB, Brazil, were used. Regarding the morphological characterization of plants, parents of $C$. annuum (UFPB-01 and -137), C. baccatum (UFPB-72), and C. chinense 
(UFPB-128) and their interspecific hybrids $(01 \times 128 ; 72 \times 128$, and $137 \times 128)$ were characterized based on descriptors proposed by IPGRI (1995).

Morphological characterization occurred in the field using a completely randomized design with five plants and three replicates. The following traits were evaluated: plant height $(\mathrm{PH})$, crown width $(\mathrm{CW})$, stem length (SL), stem diameter (SD), leaf length (LL), petiole length $(\mathrm{PtL})$, leaf width (LW), fruit weight $(\mathrm{FW})$, fruit length $(\mathrm{FL})$, largest fruit diameter (LFD), smallest fruit diameter (SFD), peduncle length (PdL), pericarp thickness (PT), seed yield per fruit (SYF), and dry matter content (DMC).

Tocher's clustering method was used to analyze genetic divergence based on the generalized Mahalanobis distance and canonical variable analysis. The relative importance of the traits for divergence was calculated using the method proposed by Singh (1981) and the canonical variable analysis.

Regarding the molecular characterization based on RAPD, the C. annuиm parent (UFPB-01) was not examined in the analysis because of the death of the plant. Therefore, two new interspecific hybrid plants $(01 \times 128.1$ and $01 \times 128.2)$, derived from crosses between $C$. annuum (UFPB-01) and C. chinense (UFPB-128), were included.

The methodology described by Ferreira and Grattapaglia (1998), with some modifications, was employed to extract genomic DNA. Samples were subjected to polymerase chain reaction analyses, which used 17 RAPD primers (Table 1).

Table 1. Primer sequences utilized for the DNA amplification of Capsicum spp using the RAPD technique.

\begin{tabular}{|c|c|}
\hline Primer & Sequence (5'-3') \\
\hline UB - 01 & AGACGGCTCC \\
\hline UB - 02 & GTTCGGAACC \\
\hline UB - 03 & GGGCGACTAC \\
\hline UB - 04 & GTGCGCAATG \\
\hline UB - 05 & TCGCATCCAG \\
\hline UB - 06 & CAGAAGCGGA \\
\hline UB - 07 & CACAGCGACA \\
\hline UB - 08 & CAAAGCGCTC \\
\hline UB - 09 & TCCCCATCAC \\
\hline UB - 10 & TGCGGGTCCT \\
\hline UB - 11 & CAGGATTCCC \\
\hline UB - 12 & GTGGAGTCAG \\
\hline UB - 13 & AAGTCCGCTC \\
\hline UB - 14 & CAGCACTGAC \\
\hline UB - 15 & GACAGGAGGT \\
\hline UB - 16 & GGCTGCAGAA \\
\hline UB - 17 & CACACTCCAG \\
\hline
\end{tabular}

The similarity matrix was obtained by utilizing the complement (1-C) of Nei and Li's (1979) similarity coefficient, and the unweighted pair group method with arithmetic average (UPGMA) hierarchical clustering method was used. All analyses were performed using the GENES program (Cruz, 2006), and a principal component analysis (PCA) was conducted based on molecular data.

\section{RESULTS}

With the exception of $\mathrm{PH}, \mathrm{SL}$, and DMC, significant differences were found for 
most of the evaluated quantitative traits (based on the F-test at a 5\% significance level). After analyzing the heritability $\left(h^{2}\right)$ values obtained in this study, the results indicated that of the plant size-related traits, PtL exhibited the highest $\mathrm{h}^{2}$ value (92.93\%) (Table 2).

Table 2. Summary of the variance (SV) analyses for quantitative plant- and fruit-related traits in Capsicum parents and interspecific hybrids.

\begin{tabular}{l|c|c|c|c|c|c|c|c}
\hline SV & PH & CW & SL & SD & LL & PtL & LW & FW \\
\hline Treatment & $598.43 \mathrm{~ns}$ & $823.83^{*}$ & $118.83 \mathrm{~ns}$ & $0.52^{*}$ & $6.28^{*}$ & $1.29^{*}$ & $6.76^{*}$ & $105.53^{*}$ \\
\hline $\mathrm{h}^{2}(\%)$ & 50.52 & 68.94 & 39.57 & 73.74 & 89.40 & 92.93 & 91.46 & 97.68 \\
\hline $\mathrm{CVg} / \mathrm{CVe}$ & 0.58 & 0.86 & 0.46 & 0.96 & 1.67 & 2.09 & 1.88 & 3.75 \\
\hline $\mathrm{CV}$ & 26.14 & 22.20 & 45.39 & 29.85 & 11.42 & 14.51 & 20.20 & 44.61 \\
\hline $\mathrm{SV}$ & FL & LFD & SFD & PdL & PT & SYF & DMC \\
\hline Treatment & $2.22^{*}$ & $2.64^{*}$ & $0.11^{*}$ & $0.92^{*}$ & $0.036^{*}$ & $1752.93^{*}$ & $155.62 \mathrm{~ns}$ \\
\hline $\mathrm{h}^{2}(\%)$ & 98.64 & 97.79 & 88.18 & 96.25 & 96.94 & 98.84 & 65.01 \\
\hline $\mathrm{CVg} / \mathrm{CVe}$ & 4.92 & 3.84 & 1.57 & 2.92 & 3.25 & 5.34 & \multicolumn{2}{c}{0.78} \\
\hline $\mathrm{CV}$ & 10.16 & 14.44 & 12.19 & 8.46 & 14.96 & 20.00 & \multicolumn{2}{c}{43.88}
\end{tabular}

*Significant at $5 \%$ probability based on the $\mathrm{F}$ test. Plant height $(\mathrm{PH})$; crown width $(\mathrm{CW})$; stem length (SL); stem diameter (SD); leaf length (LL); petiole length (PtL); leaf width (LW); fruit weight (FW); fruit length (FL); largest fruit diameter (LFD); smallest fruit diameter (SFD); peduncle length (PdL); pericarp thickness (PT); seed yield per fruit (SYF); dry matter content (DM).

Regarding the $\mathrm{CVg} / \mathrm{CVe}$ ratio, values greater than 1.0 were found for the following variables: LL, 1.67; PtL, 2.09; LW, 1.88; FW, 3.75; FL, 4.92; LFD, 3.84; SFD, 1.57; PdL, 2.92, PT, 3.25; and SYF, 5.34 (Table 2).

Significant differences were observed in SD, which exhibited different classes (Table 3). Hybrid $01 \times 128$ showed a higher average $(1.83 \mathrm{~cm})$, however, not differing from hybrids $72 \times 128,137 \times 128$ and parent 128 . While the parents 01 and 137 had the lowest average values (0.52 and 0.55$)$, respectively (Table 3$)$.

Table 3. Mean values for seven plant- and fruit size-related traits in Capsicum parents and interspecific hybrids.

\begin{tabular}{|c|c|c|c|c|c|c|c|c|}
\hline Accession & $\mathrm{PH}$ & $\mathrm{CW}$ & $\mathrm{SL}$ & SD & $\mathrm{LL}$ & $\mathrm{PtL}$ & LW & FW \\
\hline 01 & $28.00 \mathrm{ab}$ & $30.20 \mathrm{~b}$ & $14.30 \mathrm{a}$ & $0.52 \mathrm{c}$ & $6.61 b c$ & $1.70 \mathrm{bc}$ & $3.12 \mathrm{~b}$ & $0.22 \mathrm{c}$ \\
\hline $72 \times 128$ & $68.66 \mathrm{a}$ & $68.66 \mathrm{a}$ & $20.66 \mathrm{a}$ & $1.21 \mathrm{ab}$ & $6.77 b c$ & $1.77 \mathrm{bc}$ & $3.35 \mathrm{~b}$ & $0.93 b$ \\
\hline $137 \times 128$ & $72.33 \mathrm{a}$ & $86.33 a$ & $27.33 \mathrm{a}$ & $1.46 \mathrm{ab}$ & 7.62ab & $2.51 \mathrm{ab}$ & $4.07 b$ & $0.83 b$ \\
\hline $01 \times 128$ & $82.66 \mathrm{a}$ & $79.33 \mathrm{a}$ & $20.00 \mathrm{a}$ & $1.83 \mathrm{a}$ & $5.32 \mathrm{c}$ & $1.64 \mathrm{c}$ & $2.26 \mathrm{~b}$ & $0.45 b$ \\
\hline 128 & $82.66 \mathrm{a}$ & $44.66 \mathrm{a}$ & $11.00 \mathrm{a}$ & $0.98 \mathrm{ab}$ & $6.73 b c$ & $1.47 \mathrm{c}$ & $2.93 \mathrm{~b}$ & $1.21 \mathrm{~b}$ \\
\hline 72 & $45.00 \mathrm{ab}$ & $81.00 \mathrm{a}$ & $14.33 \mathrm{a}$ & $0.75 b$ & $9.27 \mathrm{a}$ & $3.02 \mathrm{a}$ & $6.17 \mathrm{a}$ & $14.10 \mathrm{a}$ \\
\hline 137 & $29.00 \mathrm{ab}$ & $19.60 \mathrm{c}$ & $10.00 \mathrm{a}$ & $0.55 \mathrm{c}$ & $6.00 \mathrm{c}$ & $1.69 \mathrm{bc}$ & $2.66 \mathrm{~b}$ & $1.18 \mathrm{~b}$ \\
\hline Accession & FL & LFD & SFD & $\mathrm{PdL}$ & PT & SYF & \multicolumn{2}{|c|}{ DMC } \\
\hline 01 & $0.87 \mathrm{c}$ & $0.66 \mathrm{c}$ & $0.45 \mathrm{c}$ & $1.59 \mathrm{c}$ & $0.11 \mathrm{~b}$ & $17.60 \mathrm{~b}$ & \multicolumn{2}{|c|}{$13.00 \mathrm{a}$} \\
\hline $72 \times 128$ & $1.14 \mathrm{c}$ & $1.18 \mathrm{~b}$ & $0.89 \mathrm{~b}$ & $2.14 b$ & $0.20 \mathrm{~b}$ & $2.66 \mathrm{c}$ & \multicolumn{2}{|c|}{$12.89 \mathrm{a}$} \\
\hline $137 \times 128$ & $1.15 \mathrm{c}$ & $1.08 \mathrm{~b}$ & $0.86 \mathrm{~b}$ & $1.55 \mathrm{c}$ & $0.16 \mathrm{~b}$ & $3.33 \mathrm{c}$ & \multicolumn{2}{|c|}{$23.98 \mathrm{a}$} \\
\hline $01 \times 128$ & $1.13 \mathrm{c}$ & $1.16 \mathrm{~b}$ & $0.72 b$ & $2.04 b c$ & $0.15 b$ & $10.33 \mathrm{c}$ & \multicolumn{2}{|c|}{$14.85 \mathrm{a}$} \\
\hline 128 & $2.02 b$ & $1.42 \mathrm{~b}$ & $0.95 \mathrm{ab}$ & $2.18 \mathrm{~b}$ & $0.19 \mathrm{~b}$ & $40.00 \mathrm{~b}$ & \multicolumn{2}{|c|}{$24.41 \mathrm{a}$} \\
\hline 72 & $3.09 \mathrm{a}$ & $3.22 \mathrm{a}$ & $1.24 \mathrm{a}$ & $3.09 \mathrm{a}$ & $0.42 \mathrm{a}$ & $56.00 \mathrm{a}$ & \multicolumn{2}{|c|}{$7.91 \mathrm{a}$} \\
\hline 137 & $2.18 \mathrm{~b}$ & $0.94 b$ & $0.55 \mathrm{c}$ & $2.02 b c$ & $0.12 b$ & $32.00 \mathrm{~b}$ & \multicolumn{2}{|c|}{$24.20 \mathrm{a}$} \\
\hline
\end{tabular}

Mean values followed by the same letter do not differ statistically according to the Tukey test at 5\% probability. Plant height $(\mathrm{PH})$; crown width $(\mathrm{CW})$; stem length (SL); stem diameter (SD); leaf length (LL); petiole length (PtL); leaf width (LW); fruit weight (FW); fruit length (FL); largest fruit diameter (LFD); smallest fruit diameter (SFD); peduncle length (PdL); pericarp thickness (PT); seed yield per fruit (SYF); dry matter content (DMC). 
The PT trait formed two classes, and the parent 72 stood out the most with an average value of 0.42 , thus forming a separate class (Table 3).

Based on SYF, variation occurred between the accessions, and three classes were formed, which varied (on average) from three (hybrid 72x128) to 56 seeds (parent 72).

In the study of diversity, the accessions were grouped using Tocher's method, which is based on the generalized Mahalanobis distance. The parents and hybrids were gathered into three groups (Table 4), and group 1 comprised most of the evaluated genotypes, including hybrids $72 \times 128,137 \times 128$, and $01 \times 128$ and parent 01 .

Table 4. Clustering of Capsicum parents and hybrids based on Tocher's method.

\begin{tabular}{l|c}
\hline Group & Accession \\
\hline 1 & $72 \times 128,137 \times 128,01 \times 128$ \\
\hline 2 & 128,137 \\
\hline 3 & 72 \\
\hline
\end{tabular}

The results of the canonical variable analysis indicated that phenotypic diversity was detected between the analyzed Capsicum accessions, and the first three canonical variables explained $99.97 \%$ of the total variance (Table 5).

The method of Singh (1981) was used to evaluate the relative importance of the 15 quantitative traits, and only six traits contributed approximately $80.00 \%$ of the genetic diversity (Table 6). The traits that contributed the most were LFD (26.42\%), SYF (15.69\%), LL (15.42\%), SD (6.38\%), LW (5.98\%), and PdL (5.43\%) (Table 6).

Regarding the molecular characterization, the 17 primers utilized for DNA amplification of the seven Capsicum accessions resulted in 58 polymorphic bands, and each primer produced an average of 3.41 bands. Some primers did not amplify some individuals, and the UB-6 and 7 primers showed the highest amplification number. The clustering analysis, based on the RAPD polymorphic loci, revealed genetic dissimilarity, which varied from $9.62 \%$ ( $72 \times 128$ with $01 \times 128.1$ ) to $58.33 \%$ ( 72 with $01 \times 128.2$ ).

The $72 \times 128$ hybrid was only amplified by primers 7,14 , and 15 . However, genotypes $137 \times 128,128,72,01 \times 128.1$, and $01 \times 128.2$ were amplified by most of the primers. According to Table 7, the smallest genetic distance (0.0962) was recorded for the pair of interspecific hybrids $72 \times 128$ and $01 \times 128$. Three additional genotypic pairs (combinations of hybrid $72 \times 128$ with hybrid $137 \times 128$, hybrid $01 \times 128.2$, and parent 128) displayed the same genetic distance ( 0.1633 ) based on data obtained using the 17 primers, which indicated that they were very close genetically. The only differences between these two pairs of genotypes were the contributions of parents 137 (C. annuum) and 72 (C. baccatum), which both contributed $50.0 \%$ of their genes in the formation of hybrids $137 \times 128$ and $72 \times 128$, respectively. However, considering the $72 \times 128$ and $137 \times 128$ hybrid pairs, it was observed that parent 128 (C. chinense) contributed $50.0 \%$ of its genes to the genetic distance, whereas parents 72 and 137 only contributed $25.0 \%$. Concerning the other pair of genotypes, $72 \times 128$ with 128 , parent 128 contributed $75.0 \%$ of its genes to genetic diversity, while parent 72 only contributed $25.0 \%$. Thus, their influence on the genetic distance was even more marked, thereby increasing the similarity between the two genotypic pairs. 


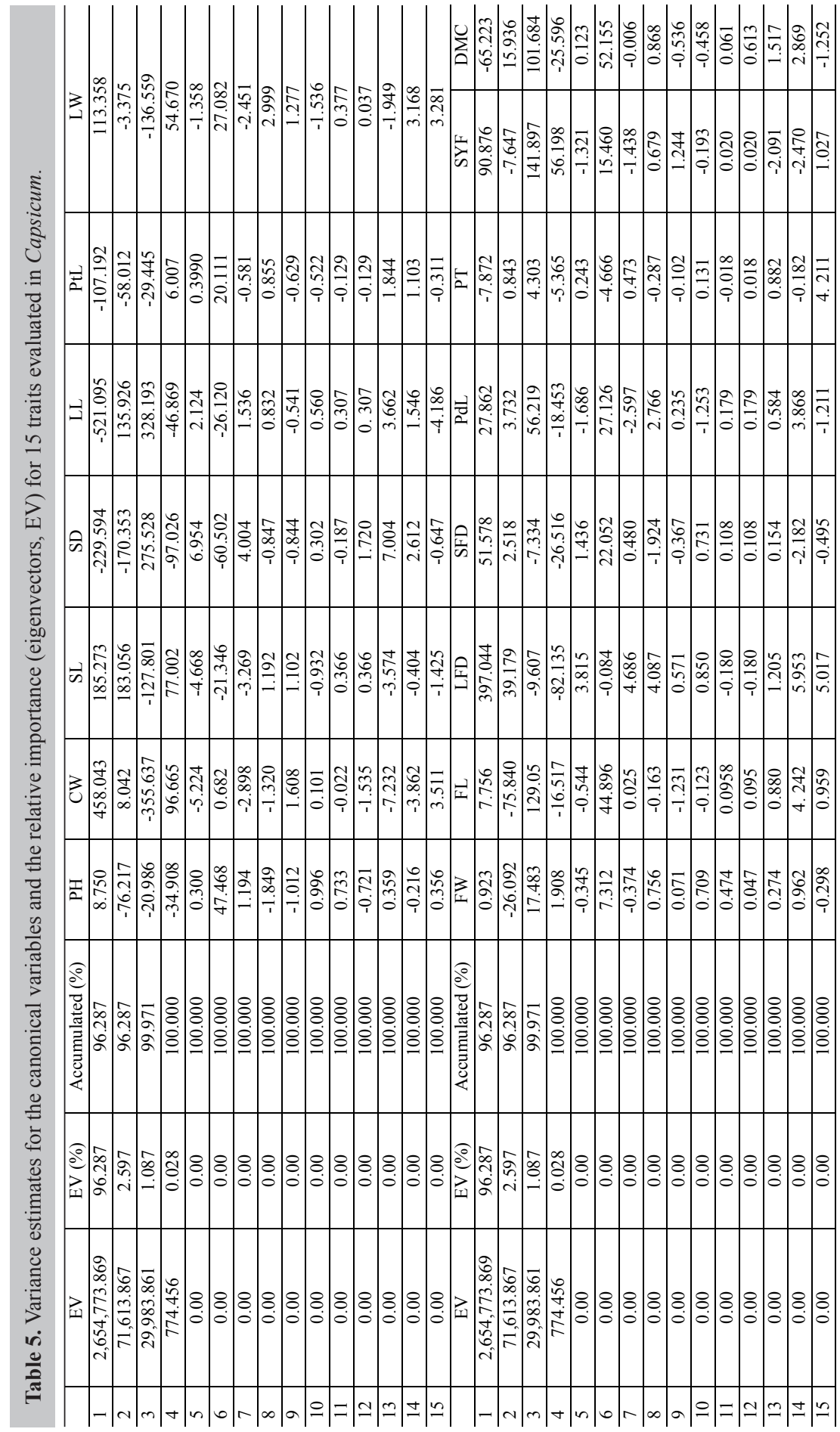


Table 6. Relative contribution of traits to diversity (Singh, 1981) based on the generalized Mahalanobis distance.

\begin{tabular}{l|c}
\hline Variable & Value (\%) \\
\hline Plant height & 0.91 \\
\hline Crown width & 2.09 \\
\hline Stem length & 3.48 \\
\hline Stem diameter & 6.38 \\
\hline Leaf length & 15.42 \\
\hline Petiole length & 3.92 \\
\hline Leaf width & 5.98 \\
\hline Fruit weight & 1.53 \\
\hline Fruit length & 6.54 \\
\hline Largest fruit diameter & 26.42 \\
\hline Smallest fruit diameter & 0.71 \\
\hline Peduncle length & 5.43 \\
\hline Pericarp thickness & 0.33 \\
\hline Seed yield per fruit & 15.69 \\
\hline Dry matter content & 2.67 \\
\hline
\end{tabular}

Table 7. Similarity matrix obtained based on the complement (1-C) of Nei and Li's (1979) coefficient from RAPD data between Capsicum parents and specific hybrids.

\begin{tabular}{l|c|c|c|c|c|c|c}
\hline Individual & $72 \times 128$ & $137 \times 128$ & 128 & 72 & 137 & $01 \times 128.1$ & $01 \times 128.2$ \\
\hline $72 \times 128$ & 0.0000 & 0.1633 & 0.1633 & 0.5405 & 0.2258 & $\underline{0.0962}$ & 0.1633 \\
\hline $137 \times 128$ & & 0.0000 & 0.2128 & 0.4615 & 0.3103 & 0.1875 & 0.2128 \\
\hline 128 & & & 0.0000 & 0.5000 & 0.2528 & 0.2128 & 0.2667 \\
\hline 72 & & & & 0.0000 & 0.3412 & 0.4250 & 0.5833 \\
\hline 137 & & & & & 0.0000 & 0.1753 & 0.2000 \\
\hline $01 \times 128.1$ & & & & & & 0.0000 & 0.2128 \\
\hline $01 \times 128.2$ & & & & & & & 0.0000 \\
\hline
\end{tabular}

The genotypic pair that showed the largest genetic distance was 72 and $01 \times 128.1$, with a distance of 0.5833 . Parent 72 is $C$. baccatum, while hybrid $01 \times 128.1$ is formed from the parents of two different species ( $C$. annuum and $C$. chinense, respectively).

A UPGMA clustering analysis was performed to group individuals based on the genetic diversity between the parents and hybrids using RAPD markers, and two groups were formed (Figure 1). The first group included parents 128 and 137 as well as all hybrid combinations $(72 \times 128,01 \times 128.1,01 \times 128.2$, and $137 \times 128)$. The second group contained a single element, parent 72 .

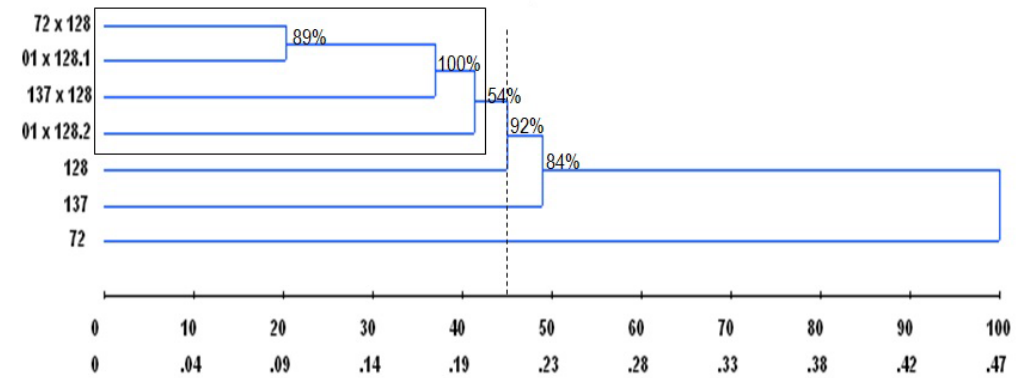

Figure 1. Genetic similarity (Nei and Li's coefficient) dendrogram that is based on the RAPD band patterns. Genetic relationships between parents and interspecific hybrids of Capsicum spp are shown. 
The PCA results grouped the parents and interspecific hybrids according to their parentage relationship, which indicated the clustering of parents and hybrids of closer species into a larger group [e.g., parents 128 (C. chinense), 137, and 01 (C. annuum) and the hybrids originating from these parents]. However, the second group only contained parent $72(C$. baccatum) (Table 7).

\section{DISCUSSION}

High heritability values found in this study indicate high genetic control in the selection trait, because it reflects the genetic proportion of the phenotypic values, making it possible to obtain gains via selection. Working with C. baccatum, Rêgo et al. (2011b) observed traits with high $\mathrm{h}^{2}$ values, which demonstrated high genetic control compared to the environmental effect.

Greater $\mathrm{CVg} / \mathrm{CVe}$ ratio results indicated that variables could be selected, and that they could provide genetic gain. Moreover, this result agreed with the $\mathrm{h}^{2}$ values described in Rêgo et al. (2011c) and Nascimento et al. (2012), which examined C. baccatum and C. annuum, respectively, and found values $>1$ for some of the traits evaluated in this study. Nascimento et al. (2012) reported that $\mathrm{CVg} / \mathrm{CVe}$ values $<1$ indicated unfavorable conditions for selection, because the genetic variation surpassed the environmental variation.

Regarding the characteristics SD, the hybrids were superior to the parents. Furthermore, similar data were found by Geleta et al. (2005) and Nascimento et al. (2012) for this trait in studies of genetic diversity in the hybrids and parents of $C$. annuиm. These authors concluded that this trait was efficient for the discrimination of hybrids from parents.

Analysis of these values indicated that the differences observed in parent 72 , in relation to those characteristics LL, PtL, LW, FW, FL, LFD, SFD, and PdL were pronounced because its species (C. baccatum) had superior traits compared to the other species. These results corroborated those found by Rêgo et al. (2011c), which examined different $C$. baccatum accessions and found large differences in the morphological traits of mature fruits.

According to Lannes et al. (2007) and Rêgo et al. (2011a), this trait PT is important for the selection of more adequate varieties for the sale of fresh products, because they are resistant to post-harvest damage.

The lower number of seeds observed in the hybrids relative to the parents is probably due the unviable pollen of the interspecific hybrids, which contributes to a lower seed yield. It is important to note that it is extremely difficult to obtain good interspecific hybrids with regard to this trait (Rêgo et al., 2009). According to Nascimento et al. (2011), hybrid seeds do not always exhibit good vigor and germination, particularly when they originate from interspecific crosses.

In the adoption of Tocher's optimization method based on Mahalanobis's distance, the results show that although in the group 1 are included interspecific crosses, it showed that the species belonging to these groups were close, especially regarding traits related to plant and fruit size. Group 2 consisted of parents 128 (C. chinense) and 137 (C. annuum), which are two species that belong to the same phylogenetic group, while the Group 3 only included parent $72(C$. baccatum), which is distantly related to $C$. annuum and $C$. chinense. Depending on the objectives of the breeding program, the traits associated with the divergence of parent 72 can be improved.

By the method of canonical variables, similar data were found by Rêgo et al. (2011c), in which the first three canonical variables associated with Capsicum explained approximately $81.94 \%$ of the total variance. When the first three canonical variables explain more than 70.0 , 
there is strong evidence that the data fit a tridimensional graphic representation (Rêgo et al., 2003; Bento et al., 2007). The graphic dispersion enabled the separation of the accessions into groups, so this method could be used as a strategy to select diverging genotypes for utilization in artificial crosses (Neitzke et al., 2010). In the dispersion graph (Figure 2), the clustering was compatible with the groups composed using Tocher's method, because three groups were formed in both cases. According the canonical variables method, the traits that showed the highest eigenvectors at the last eigenvalues (which were subject to being discarded) were LL, LFD, CW, SD, PH, and LW (Table 5). However, additional methods were required to determine if these traits were actually subject to being discarded.

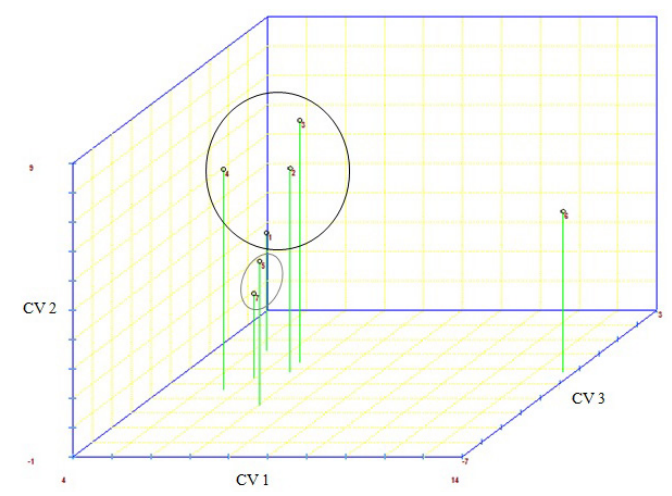

Figure 2. Graphic dispersion of scores relative to the axes, which represent the first three canonical variables (CV) that refer to the 15 examined Capsicum traits. $1=01 ; 2=72 \times 128 ; 3=137 \times 128 ; 4=01 \times 128 ; 5=128 ; 6=72 ;$ and $7=137$.

Based on studies conducted by Sudré et al. (2005), using the method of Singh, only two traits assessed in this study coincided with those described, by which examined 56 Capsicum accessions. The same authors found that the traits that most contributed to divergence were LFD $(31.06 \%)$ and SYF $(13.35 \%)$, and the traits that contributed least to genetic diversity were SFD (0.71\%), PH (0.91\%), CW (2.09\%), PtL (3.93\%), FW (1.53\%), DMC (2.67\%), and SL (3.48\%) (Table 6), resulting in minimal importance for the clustering of the evaluated hybrids and parents. Variables that contributed a very low percentage or those that did not contribute at all to the detected variability may be discarded in future studies of genetic diversity (Rêgo et al., 2003).

Regarding the determination of divergence, the traits of least importance included $\mathrm{PH}$ and $\mathrm{CW}$, and these results corresponded with those obtained using the canonical variables and Singh (1981) methods. Considering the examination of these hybrids and parents, these traits could be expendable in future genetic diversity studies.

Regarding the molecular characterization, the amplified bands were monomorphic, and this result likely stems from the fact that several Capsicum species were involved. Williams et al. (1990) reported that a single change in one nucleotide could prevent the entire amplification.

The RAPD markers revealed that the parents 137 and 72 had little influence on the genetic diversity of hybrid pair $72 \times 128$ and $137 \times 128$. This result was corroborated by the fact that a distance of 0.3103 was found when we considered the genetic diversity between the genotypic pair $137 \times 128$ and parent 137 in the distance matrix. This distance was higher than 0.1633 , which indicated that the influence of parent 128 increased the similarity between parents and hybrids. Likewise, the distance was even greater (0.5405) in the genotypic pair 
72x128 and 72. In their C. annuum study, Paran et al. (1998) found an average distance of 0.7 between the genotypic pairs belonging to this species. Genetic distances of a great magnitude allow the selection of genotypes with a broad genetic base.

The pair that showed the largest genetic distance is formed from parent $72(C$. baccatum $)$ with a simple hybrid $(01 \times 128)$ derived of two different species $(C$. annuum and $C$. chinense, respectively). This distance was expected, since it represents the distance between a pair of parents derived from three different species (i.e., three different genomes). Similar results were observed by Thul et al. (2012) who used RAPD and SRR markers to examine 22 Capsicum accessions that were native to India, and the results indicated that the data obtained with these markers revealed genetic similarity values of approximately 23.0 to $99.0 \%$ and 11.0 to $96.0 \%$, respectively, between the evaluated accessions.

Regarding a UPGMA clustering analysis, these data were consistent with the results of Ince et al. (2010) who examined 24 different Capsicum accessions, and the results indicated that $C$. chinense and $C$. annuum grouped together and separately from $C$. baccatum.

By multivariate analysis and using PCA, results grouped the parents and interspecific hybrids according to their parentage relationship, in addition to revealing the consistency of the PCA, which accumulated $97.13 \%$ of the diversity analyzed in the three components; these data also confirmed the morphological data that grouped the parents and hybrids into three groups (Figure 3), with parent 72 forming a single isolated group. The results also confirmed the data from the clustering analysis, which also formed the three groups. Therefore, these results provided evidence that parent 72 (C. baccatum) was genetically distant from the other parents and interspecific hybrids.

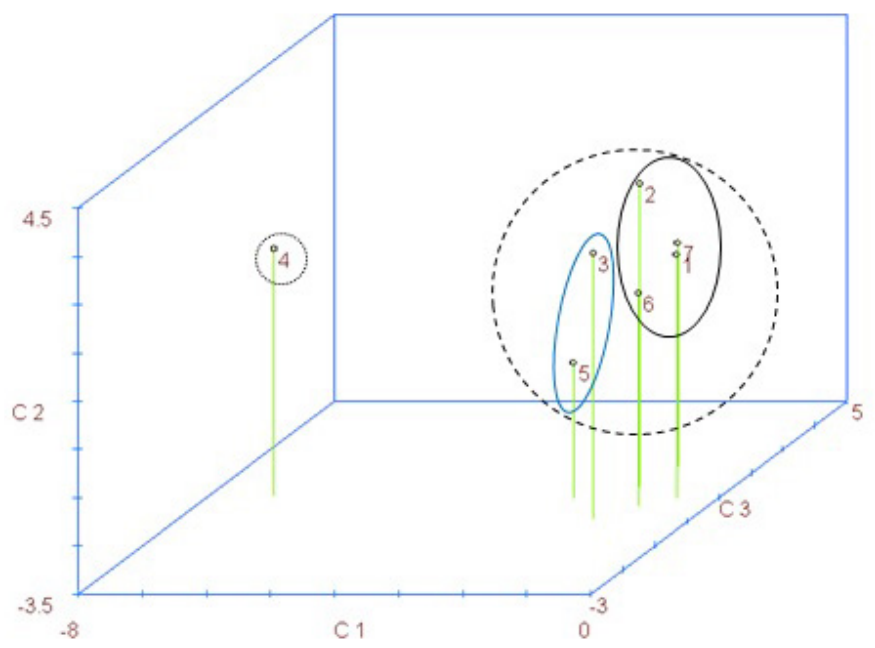

Figure 3. Graphic dispersion of the parents and interspecific hybrids based on the principal component analysis (PCA) of the genetic similarity matrix containing RAPD data. Numbers 1, 2, 6, 7, 3, and 5 form one group and correspond to hybrids $72 \times 128,137 \times 128,01 \times 128.1$, and $01 \times 128.2$ and parents 128 and 137, respectively. Parent 72 was isolated, forming the second group.

After analyzing the genetic variability of 22 pepper accessions belonging to six different species using RAPD and inter-simple sequence repeat (ISSR) molecular markers and PCA, Thul et al. (2012) observed that $C$. annuum was genetically closer to $C$. chinense, 
followed in order by $C$. frutescens, C. baccatum, C. luteum, and C. eximium. The results obtained from the taxonomy study, the evaluation of genetic diversity of domesticated species in the Andean region, and the genetic diversity between different Capsicum species based on amplified fragment length polymorphism (AFLP), simple sequence repeat (SSR), and RAPD molecular markers also indicated that $C$. annuиm and $C$. chinense were more closely related, and that $C$. baccatum was the most distant (Ince et al., 2010; Ibiza et al., 2012). These results confirmed the data found in the present study, since parent 72 (C. baccatum) formed a separate group that was isolated from the larger group containing parents 128 and 137 and hybrids $72 \times 128,01 \times 128.1,01 \times 128.2$, and $137 \times 128$.

Despite sharing the same parents (i.e., full siblings), hybrids $01 \times 128.1$ and $01 \times 128.2$ were distinct. These two hybrids, which resulted from the crossing between parents UFPB-01 (C. апnиит) and UFPB-128 (C. chinense), bear fruits of different colors (red and yellow fruit, respectively). These morphological results also confirmed the data obtained from the RAPD marker using the primer UB-6, which was used to differentiate the two hybrids (data not shown).

In conclusion, the morphological and molecular data efficiently determined the genetic diversity between parents and interspecific hybrids. Moreover, the UPGMA clustering and PCA analyses separated the parents and interspecific hybrids into three groups.

\section{Conflicts of interest}

The authors declare no conflict of interest.

\section{ACKNOWLEDGMENTS}

Research supported by CAPES and CNPq for financial support and fellowship.

\section{REFERENCES}

Barroso PA, Rêgo ER, Rêgo MM, Nascimento KS, et al. (2012). Analysis of segregating generation for components of seedling and plant height of pepper (Capsicum annuum L.) for medicinal and ornamental purposes. In: XXIV International Eucarpia Symposium Section Ornamentals: Ornamental Breeding Worldwide, 953: 269-275.

Bento CS, Sudré CP, Rodrigues R, Riva EM, et al. (2007). Descritores qualitativos e multicategóricos na estimativa da variabilidade fenotípica entre acessos de pimentas. Sci. Agraria 8: 149-156. http://dx.doi.org/10.5380/rsa.v8i2.8379

Cruz CD (2006). Programa Genes: versão Windows; aplicativo computacional em genética e estatística. Viçosa: UFV.

Ferreira ME and Grattapaglia D (1998). Introdução ao uso de marcadores moleculares em análise genética. Brasília.

Geleta LF, Labuschagne MT and Viljoen CD (2005). Genetic variability in pepper (Capsicum annuum L.) estimated by morphological data and amplified fragment length polymorphism markers. Biodivers. Conserv. 14: 2361-2375. http://dx.doi.org/10.1007/s10531-004-1669-9

Ibiza VP, Blanca J, Cañizares J and Nuez F (2012). Taxonomy and genetic diversity of domesticated Capsicum species in the Andean region. Genet. Resour. Crop Evol. 59: 1077-1088. http://dx.doi.org/10.1007/s10722-011-9744-Z

Ince AG, Karaca M and Onus AN (2010). Genetic relationships within and between Capsicum species. Biochem. Genet. 48: 83-95. http://dx.doi.org/10.1007/s10528-009-9297-4

International Plant Genetic Resources Institute - IPGRI (1995). Descritores para Capsicum (Capsicum spp). Roma, IPGRI.

Lanham PG, Forster BP, McNicol P, Moss JP, et al. (1994). Seed storage protein variation in Arachis species. Genome 37: 487-496. http://dx.doi.org/10.1139/g94-068

Lannes SD, Finger FL, Schuelter AR and Casali VWD (2007). Growth and quality of Brazilian accessions of Capsicum chinense fruits. Sci. Hortic. (Amsterdam) 112: 266-270. http://dx.doi.org/10.1016/j.scienta.2006.12.029

Murphy RW, Sites JR and Buth DG (1990). Proteins I: isozyme electroforesis. In: Hillis DM, Moritz C. Molecular Systematics. Sunderland: Sinauer Associates. 45-26. 
Nascimento MF, Rêgo ER, Rêgo MM, Nascimento NFF, et al. (2011). Vigor e germinação de sementes híbridas de pimenteiras ornamentais. Rev. Bras. Hortic. Ornam. 17: 51-56.

Nascimento NFF, Rego ER, Nascimento MF, Finger FL, et al. (2012). Heritability and variability of morphological traits in a segregating generation of ornamental pepper. In: XXIV International Eucarpia Symposium Section Ornamentals: Ornamental Breeding Worldwide, 953: 299-304.

Nei M and Li WH (1979). Mathematical model for studying genetic variation in terms of restriction endonucleases. Proc. Natl. Acad. Sci. USA 76: 5269-5273. http://dx.doi.org/10.1073/pnas.76.10.5269

Neitzke RS, Barbieri RL, Rodrigues WF, Corrêa IV, et al. (2010). Dissimilaridade genética entre acessos de pimenta com potencial ornamental. Hortic. Bras. 28: 47-53. http://dx.doi.org/10.1590/S0102-05362010000100009

Paran I, Aftergoot E and Shifriss C (1998). Variation in Capsicum annuum revealed by RAPD and AFLP markers. Euphytica 99: 167-173. http://dx.doi.org/10.1023/A:1018301215945

Rêgo ER, Rêgo MM, Cruz CD, Finger FL, et al. (2003). Genetic diversity analysis of peppers: a comparison of discarding variables methods. Crop Breed. Appl. Biotechnol. 3: 19-26. http://dx.doi.org/10.12702/1984-7033.v03n01a03

Rêgo ER, Rêgo MM, Cruz CD, Finger FL, et al. (2009). Diallel study of yield components and fruit quality in chilli pepper (Capsicum baccatum). Euphytica 168: 275-287. http://dx.doi.org/10.1007/s10681-009-9947-y

Rêgo ER, Rêgo MM, Matos IWF and Barbosa LA (2011a). Morphological and chemical characterization of fruits of Capsicum spp. accessions. Hortic. Bras. 29: 364-371. http://dx.doi.org/10.1590/S0102-05362011000300018

Rêgo ER, Rego MM and Farias-Filho LP (2011b). Genetic diversity in pepper (Capsicum spp.) by RAPD marker. In: XXVIII International Horticultural Congress on Science and Horticulture for People (IHC2011): III International Symposium 918: 341-347.

Rêgo ER, Rêgo MM, Cruz CD, Finger FL, et al. (2011c). Phenotypic diversity, correlation and importance of variables for fruit quality and yield traits in Brazilian peppers (Capsicum baccatum). Genet. Resour. Crop Evol. 58: 909-918. http://dx.doi.org/10.1007/s10722-010-9628-7

Rodrigues R and Costa FRB (2011). Marcadores moleculares em pimenteira. In: Produção, genética e melhoramento de pimenta (Capisicum ssp) (Rêgo ER, Finger FL and Rêgo MM, eds.). Recife, 137-163.

Singh D (1981). The relative importance of characters affecting genetic divergence. Indian J. Genet. Plant Breed. 41: 237-245.

Sudré CP, Rodrigues R, Riva EM, Karasawa M, et al. (2005). Divergência genética entre acessos de pimenta e pimentão utilizando técnicas multivariadas. Hortic. Bras. 23: 22-27. http://dx.doi.org/10.1590/S0102-05362005000100005

Thul ST, Darokar MP, Shasany AK and Khanuja SP (2012). Molecular profiling for genetic variability in Capsicum species based on ISSR and RAPD markers. Mol. Biotechnol. 51: 137-147. http://dx.doi.org/10.1007/s12033-0119446-y

Vieira EA, Freitas Filho IJF, Bellon GF, Fonseca GKG, et al. (2010). Caracterização molecular e variabilidade genética de acessos elite de mandioca para fins industriais. Cienc. Rural 40: 2467-2471. http://dx.doi.org/10.1590/S0103$\underline{84782010001200005}$

Williams JGK, Kubelik AR, Livak KJ, Rafalski JA, et al. (1990). DNA polymorphisms amplified by arbitrary primers are useful as genetic markers. Nucleic Acids Res. 18: 6531-6535. http://dx.doi.org/10.1093/nar/18.22.6531 